\title{
A Modern History of the Kurds, 3d rev. ed.
}

\author{
David McDowall
}

London and New York: I.B. Tauris, 2005. 515 pages.

This extensive survey of the Kurds' history is divided into five sections: "The Kurds in the Age of Tribe and Empire," "Incorporating the Kurds," "Ethno-nationalism in Iran," "Ethno-nationalism in Iraq," and "Ethnonationalism in Turkey." An introduction on Kurdish identity and social for- 
mation, as well as four appendices discussing the Treaty of Sèvres and the Kurds of Syria, Lebanon, and Caucasia, are also included. David McDowall, a noted British specialist on Middle Eastern minority affairs and an acknowledged expert on Kurdish studies, has extensively revised the 1996 second edition of his book. He provides an analysis of recent Kurdish events and a more up-to-date bibliography at the end of each section.

This highly detailed history begins in the nineteenth century and ends in the present day. The author discusses the interplay of the old and new facets of Kurdish politics: local rivalries within Kurdish society; the enduring authority of the traditional leadership represented by sheikhs and aghas; the failure of modern nation states to respond to the challenge of Kurdish nationalism; and the use of Kurdish groups as pawns by major western powers and regional states in the region's power politics. His methodology is primarily political-historical in nature; however, anthropological and social analysis are not totally lacking.

As presented by McDowall, a close scrutiny of modern Kurdish history reveals striking continuities. For example, one pattern has characterized Kurdish-Iraqi relations since 1958: Each Iraqi government pursued peace negotiations with the Kurds at first, only to fight them when it felt secure about its rule. This pattern is also found in Iran's relations with its Kurds. Turkey, however, has pursued a policy that seeks to assimilate and, at times, even ethnically cleanse its Kurdish population.

There is also continuity in the major powers' manipulation of the "Kurdish card" in Iraq. McDowall writes that in 1976, the Select Intelligence Committee of the House of Representatives reported to the House that neither Iran nor the United States would like to see the civil war going on in Iraq at that time resolved in a way that would give the Kurds a clear win. Twenty years later, in 1991, the United States implemented a similar policy with the Kurds' so-called "exclusionary zone" in northern Iraq. Fearing the consequences likely to follow Saddam Hussein's overthrow - in particular, the dismemberment of Iraq and wider regional instability - the United States refused to give the Kurds sufficient aid to enable them to establish an independent homeland.

McDowall also calls attention to an equally important pattern: the persistent failure of the Kurdish elites in Iran, Iraq, and Turkey to build an articulate national movement that could bring security and freedom, as well as to create the proper mechanisms needed to achieve nationalist aspirations. In the end, the Kurdish leadership bears a significant degree of responsibility for Kurdish suffering. The Kurds have been consistently ill-served by their 
leaders, whose dictatorial tendencies, treachery, venality, and ineptness have often been in evidence. Among the examples of this, McDowall points to the 1992 Kurdish elections in the "safe haven" in northern Iraq, which were followed by a civil war of extreme brutality between the Kurdish Democratic Party and the Patriotic Union of Kurdistan.

He comments that Iran, despite its "theocratic" government, has reached a working modus vivendi in its dealings with its Kurdish population, while the secular governments of Iraq and Turkey continued to pursue policies during the twentieth century that were genocidal. This latter policy was due to the Kurds' resistance to the recently established regimes in Turkey (Atatürk) and Iraq (a British-installed monarchy), which equated modernization with state nationalism, ethnic subordination, and centralization.

In the Foreword, the author writes that he has devoted considerable space to the period between 1918-25 on the grounds that this was a formative and critical for the development of the Kurdish question. Also, it was at this time that the "Kurds lost their one great opportunity for statehood." Although this period is indeed crucial, it has already been sufficiently addressed in a number of other studies, especially by Robert Olson in The Emergence of Kurdish Nationalism: 1800-1925 (University of Texas Press: 1991). In future editions, it would be preferable if this section were revised so that it gives more attention to the period following Saddam Hussein's fall as well as Turkey's recent reappraisal of its Kurdish policy.

The book has several limitations. While the bibliography lists some Arabic and Kurdish sources, McDowall relies extensively on western sources, especially the archives of the Public Record Office in London. As a result, at times he reproduces the official British version of some events. This is especially evident in his treatment of the Kurds' role in the Armenian genocide, which he inaccurately describes as "willing." No serious academic work on the Kurds can avoid extensive use of primary sources in Kurdish, Turkish, and Persian. The author's wide range of relationships with the leading members of Kurdish communities in Iraq, Iran, and Turkey enabled him to make penetrating and insightful analyses. However, he did not enjoy the same type of close relationship with policymakers in Iraq, Iran, and Turkey. This makes his account more sympathetic to the Kurds. Nor did he have access to the relevant national archives in those countries, which would have yielded an abundance of relevant data.

Recently, the Kurds have become the focus of numerous works in western languages. However, this single-authored account has a more focused 
quality and a more lively presentation than other works. It is well-written and is a scholarly work that can be utilized as a standard text on Kurdish studies. In addition, it is indispensable reading for students of the political histories of modern Iran, Turkey, and Iraq. But due to its specialized nature, it is less accessible to the casual reader.

Othman Ali

Instructor, History Depatment, Raymond Chang School

Ryerson University, Toronto, Ontario, Canada 